\title{
Expression of Apoptotic Markers BC1-2 and Bax in the Vascular Wall
}

DOI: $10.17691 / \mathrm{stm} 2021,13.2 .05$

Received August 17, 2020

E.A. Klimentova, MD, PhD, Department of Cardiovascular, X-ray Endovascular,

Operative Surgery, and Topographic Anatomy';

1.A. Suchkov, MD, DSc, Professor, Department of Cardiovascular, X-ray Endovascular,

Operative Surgery, and Topographic Anatomy';

A.V. Shchulkin, MD, PhD, Associate Professor, Department of Pharmacology and Pharmacy,

Faculty of Supplementary Professional Education;

A.P. Glazkova, Staff Anesthesiologist;

R.E. Kalinin, MD, DSc, Professor, Head of the Department of Cardiovascular, X-ray Endovascular, Operative Surgery, and Topographic Anatomy ${ }^{1}$

'Ryazan State Medical University, 9 Vysokovoltnaya St., Ryazan, 390026, Russia;

${ }^{2}$ Ryazan Regional Clinical Hospital, 3a Internatsionalnaya St., Ryazan, 390039, Russia

The aim of the study was to assess the levels of $\mathrm{Bcl}-2$ and Bax proteins in the vascular wall and their correlation with serum cholesterol in patients with stage III-IV atherosclerosis obliterans of lower limb arteries.

Materials and Methods. The study included 32 patients with stage III-IV atherosclerosis obliterans of the lower limb. Samples of intraoperative material (all three layers of the vascular wall) including an atherosclerotic plaque (AP) were taken during primary open surgery on major leg arteries. As a control, we used samples of the arterial wall without visible signs of atherosclerosis. Based on AP ultrasonography, the patients were divided into two groups: with APs of mixed echogenicity and with hyperechoic (calcified) AP. The vascular samples were crushed and homogenized for further measurements of Bcl-2 and Bax proteins; in a separate setup, cholesterol in blood serum was measured.

Results. In patients without atherosclerotic changes, the level of the anti-apoptotic protein Bcl-2 in the arterial wall was $1.25 \mathrm{ng} / \mathrm{mg}$, and that of the pro-apoptotic protein Bax $-4.7 \mathrm{ng} / \mathrm{mg}$. In the case of APs of mixed echogenicity, the expression of Bcl-2 was $1.8 \mathrm{ng} / \mathrm{mg}$ $(p=0.143)$ and that of Bax $-5.1 \mathrm{ng} / \mathrm{mg}(p=0.834)$, with no significant differences from AP-free vascular wall samples. In the arterial wall containing a heterogeneous calcified AP, the expression of Bcl-2 was $0.9 \mathrm{ng} / \mathrm{mg}(p=0.143)$, In contrast, the level of Bax was $6.8 \mathrm{ng} / \mathrm{mg}$, which showed its significant increase as compared with the non-AP controls $(p=0.02)$. In the cases with predominantly hyperechoic AP, the expression of $\mathrm{Bcl}-2$ was significantly lower $(p=0.036)$, and that of $\mathrm{Bax}-$ significantly higher $(p=0.036)$ in comparison with AP of mixed echogenicity. In patients with hyperechoic AP, we found a negative correlation between the Bax and Bcl-2 values $(r=-0.315)$ and a positive correlation between the Bax expression and serum cholesterol ( $r=0.617)$.

Conclusion. In arterial walls with hyperechoic (calcified) APs, the expression of anti-apoptotic protein Bcl-2 is reduced, and that of pro-apoptotic protein Bax is increased, which indicates the apoptosis activation in advanced atherosclerotic lesions. In patients with such APs, elevated cholesterol levels directly correlate with the increased expression of pro-apoptotic Bax protein ( $r=0.617$ ).

Key words: atherosclerotic plaque; apoptotic proteins; Bax and Bcl-2 proteins; lower limb arterial atherosclerosis; cholesterol.

How to cite: Klimentova E.A., Suchkov I.A., Shchulkin A.V., Glazkova A.P., Kalinin R.E. Expression of apoptotic markers Bcl-2 and Bax in the vascular wall. Sovremennye tehnologii v medicine 2021; 13(2): 46, https://doi.org/10.17691/stm2021.13.2.05

\section{Introduction}

Large groups of population in developed countries all over the world suffer from atherosclerosis of coronary, carotid, or peripheral arteries. Development of atherothrombotic complications remains the main cause of lethal outcomes [1-4].

An important role in maintaining the physiological cellular homeostasis is played by the mechanism of apoptosis, i.e. programmed cell death. Dysregulation of apoptosis is associated with infectious and oncological diseases, as well as with atherosclerosis [5]. Among other factors, atherosclerosis is caused by the accumulation of oxidized low-density lipoproteins (oLDL) and inflammatory cytokines in the vascular wall. Apoptosis of macrophages, smooth muscle cells (SMCs), and endothelial cells contributes to arterial atherosclerosis as well [6]. Werner et al. [7] showed that an increase in the number of apoptotic micro-particles led to the development of severe endothelial dysfunction

Corresponding author: Emma A. Klimentova, e-mail: klimentova.emma@yandex.ru 
due to increased endothelial permeability, followed by migration of inflammatory cells and proliferation of SMCs. Others [8] found that a decrease in the level of microRNA-34a facilitated the growth of endothelial cells and inhibited cell apoptosis in an atherosclerotic plaque (AP) by activating the anti-apoptotic protein $\mathrm{Bcl}-2$; this observation suggested a promising therapeutic option for atherosclerosis.

It is known that APs contain a large number of dead cells, which can account for up to $80 \%$ of the total AP structure. A ruptured fibrous cap in the "necrotic core" of an AP is considered a major cause of arterial thrombosis. Most of the studies on apoptosis of vascular wall cells were carried out in animals. It was shown that in the early stages of atherosclerosis, cell apoptosis counteracted and balanced cell proliferation. In the later stages though, apoptosis of SMCs and macrophages prevailed and led to the development of lipid-enriched necrotic areas [9].

The $\mathrm{Bcl}-2$ protein family is one of the major players in the apoptosis system; these proteins participate in the regulation of the mitochondrial membrane permeability. The proteins of this family are classified as either proapoptotic (Bax, Bak, etc.) or anti-apoptotic (Bcl-2, etc.). The ratio between these two groups is considered predictive of the forthcoming cell death. After receiving a specific signal, Bax or Bak proteins undergo conformational changes and move into the mitochondrial membrane, where they promote the release of cytochrome $\mathrm{C}$ into the cytosol $[10,11]$.

There are studies on Bcl-2 and Bax proteins in coronary and carotid arteries of animals. However, we found no reports on the expression of these proteins in vascular wall samples taken from patients with lower limb atherosclerosis obliterans (ASO). Yet, the status of these apoptotic markers in ASO patients could provide additional information on the pathogenesis and complications of atherosclerosis.

The aim of the study was to assess the expression of Bcl-2 and Bax proteins in the vascular wall and their correlation with serum cholesterol in patients with stage III-IV atherosclerosis obliterans of lower limb arteries.

\section{Materials and Methods}

The study included 32 male patients $(63.4 \pm 7.9$ years old) with stage III-IV ASO who were treated at the Unit of Vascular Surgery of the Ryazan Regional Clinical Hospital (Russia). Upon admission, all patients underwent routine diagnostic tests including angiography and duplex ultrasonography of lower limb arteries.

After receiving informed consent from the patients, samples of the arterial wall were taken during surgery on main leg arteries. The sampled material represented all three layers of a vascular wall segment containing an AP. As a control $(n=12)$, we used samples of the arterial walls obtained posthumously during organ explantation from subjects without ASO.

Based on the ultrasound characteristics of their APs, patients were divided into two groups: with mixed echogenicity (group 1, $n=16$ ) and with hyperechoic (calcified) AP (group 2, n=16) (Table 1).

The withdrawn sample was crushed and added with a lysis buffer (Thermo Fisher Scientific, USA). The mixture was centrifuged at $24,000 \mathrm{rpm}$ for $60 \mathrm{~s}$ at $2^{\circ} \mathrm{C}$. The resulting homogenate was spinned down again at $1000 \mathrm{~g}$ for $10 \mathrm{~min}$ at $2^{\circ} \mathrm{C}$. In the resulting supernatant, the amount of Bcl-2 protein was determined using a commercial ELISA kit (Thermo Fisher Scientific) and the Bax protein - with a Cloud-Clone Corporation kit (China, USA). The results were then recalculated per protein content; the latter was measured by using the Bradford method with Coomassie Plus (Bradford) Assay Kit (Thermo Fisher Scientific).

Statistical data analysis was performed using the Statistica 10.0 software package. Since the primary data deviated from the normal distribution pattern (according to the Shapiro-Wilk test, $\mathrm{p}<0.05)$, nonparametric tests were used for data analysis. Specifically, the Wilcoxon test was used to compare two interdependent groups, the Mann-Whitney $U$ test - to compare two independent groups, and the Spearman's test - for correlation analysis. The results were considered statistically significant at $p<0.05$.

Table 1

Characteristics of the studied samples

\begin{tabular}{|c|c|c|c|c|c|c|}
\hline \multirow[b]{2}{*}{$\begin{array}{l}\text { Ultrasound characterization } \\
\text { of the vascular wall }\end{array}$} & \multicolumn{2}{|c|}{ Stage of the disease } & \multirow[b]{2}{*}{$\begin{array}{l}\text { Number } \\
\text { of samples }\end{array}$} & \multicolumn{3}{|c|}{ Sampled vessel } \\
\hline & III & IV & & $\begin{array}{l}\text { External } \\
\text { iliac artery }\end{array}$ & $\begin{array}{l}\text { Femoral } \\
\text { artery }\end{array}$ & $\begin{array}{l}\text { Popliteal } \\
\text { artery }\end{array}$ \\
\hline Intact arterial wall & - & - & 12 & 4 & 4 & 4 \\
\hline $\begin{array}{l}\text { Atherosclerotic plaque } \\
\text { with mixed echogenicity }\end{array}$ & 10 & 6 & 16 & 4 & 8 & 4 \\
\hline $\begin{array}{l}\text { Hyperechoic (calcified) } \\
\text { atherosclerotic plaque }\end{array}$ & 6 & 10 & 16 & 3 & 7 & 6 \\
\hline
\end{tabular}




\section{Results}

Our study showed that in the arterial wall without atherosclerotic changes (control group), the level of $\mathrm{Bcl}-2$ was $1.25 \mathrm{ng} / \mathrm{mg}$ protein, $\mathrm{Bax}-4.7 \mathrm{ng} / \mathrm{mg}$, and the $\mathrm{Bcl}-2 / \mathrm{Bax}$ ratio was 0.26 . The serum cholesterol level was $4.2 \mathrm{mmol} / \mathrm{L}$.

In the arterial wall containing an AP of mixed echogenicity, Bcl-2 was present at $1.8 \mathrm{ng} / \mathrm{mg}, \mathrm{Bax}-$ $5.1 \mathrm{ng} / \mathrm{mg}$, and the ratio of Bcl-2 to Bax was 0.3. The level of serum cholesterol was $4.4 \mathrm{mmol} / \mathrm{L}$. The above values did not significantly differ from the respective values in the control group.

In the arterial wall containing a heterogeneous (calcified) AP, the level of $\mathrm{Bcl}-2$ was $0.9 \mathrm{ng} / \mathrm{mg}$ protein, that of Bax $-6.8 \mathrm{ng} / \mathrm{mg}$, and their ratio was 0.13 . The cholesterol level was $7.0 \mathrm{mmol} / \mathrm{L}$, which was significantly higher than that in control $(p<0.05)$. The Bax protein level was significantly $(p<0.05)$ increased in comparison with its level in the arterial wall without atherosclerosis (Table 2).

In APs with a predominance of the hyperechoic component, the expression of $\mathrm{Bcl}-2$ was significantly lower $(p<0.05)$, and the expression of Bax was higher $(p<0.05)$ in comparison with their expression in APs with mixed echogenicity.

In patients with hyperechoic (calcified) AP, there was a negative correlation between the levels of $B a x$ and $\mathrm{Bcl}-2$ ( $r=-0.315$; Figure 1) and a positive correlation between the level of Bax and that of serum cholesterol $(r=0.617$; Figure 2).

\section{Discussion}

In this study, the levels of $\mathrm{Bcl}-2$ and Bax proteins expressed in the intact arterial wall of human peripheral arteries were determined. Normally, cells of an intact vessel demonstrate highly efficient clearance of apoptotic bodies by phagocytes and neighboring cells without the development of an inflammatory reaction, which is necessary for the normal development and functioning of the cell [12].

In atherosclerotic lesions, the expression of these proteins changes in two opposite ways. In hyperechoic (calcified) APs, the level of $\mathrm{Bcl}-2$ is reduced, and the level of Bax is increased as compared with their levels in APs of mixed echogenicity. This may be due to the

Table 2

Levels of proteins $\mathrm{Bcl}-2$ and $\mathrm{Bax}$ in vascular wall homogenates and cholesterol in the blood serum (Me [Q1; Q3])

\begin{tabular}{|c|c|c|c|c|}
\hline $\begin{array}{l}\text { Segments } \\
\text { of the arterial wall }\end{array}$ & Bcl-2 (ng/mg) & Bax (ng/mg) & $\mathrm{Bcl}-2 / \mathrm{Bax}$ & $\begin{array}{c}\text { Cholesterol } \\
\text { (mmol/L) }\end{array}$ \\
\hline $\begin{array}{l}\text { Arterial wall without visible signs } \\
\text { of atherosclerosis }\end{array}$ & $1.25[1.21 ; 1.30]$ & $4.7[3.8 ; 5.6]$ & $0.26[0.20 ; 0.30]$ & $4.2[3.2 ; 4.3]$ \\
\hline $\begin{array}{l}\text { Atherosclerotic plaque with mixed } \\
\text { echogenicity }\end{array}$ & $1.80[1.60 ; 1.83]$ & $5.1[1.3 ; 5.1]$ & $0.30[0.40 ; 1.30]$ & $4.4[3.2 ; 5.7]$ \\
\hline $\begin{array}{l}\text { Hyperechoic (calcified) } \\
\text { atherosclerotic plaque }\end{array}$ & $0.90[0.60 ; 1.20]^{*}$ & $6.8[6.3 ; 7.1]^{*}$ & $0.13[0.09 ; 0.14]^{*}$ & $7.0[4.2 ; 7.3]$ \\
\hline
\end{tabular}

* Statistically significant differences $(p<0.05)$ from values for atherosclerotic plaque of mixed echogenicity.

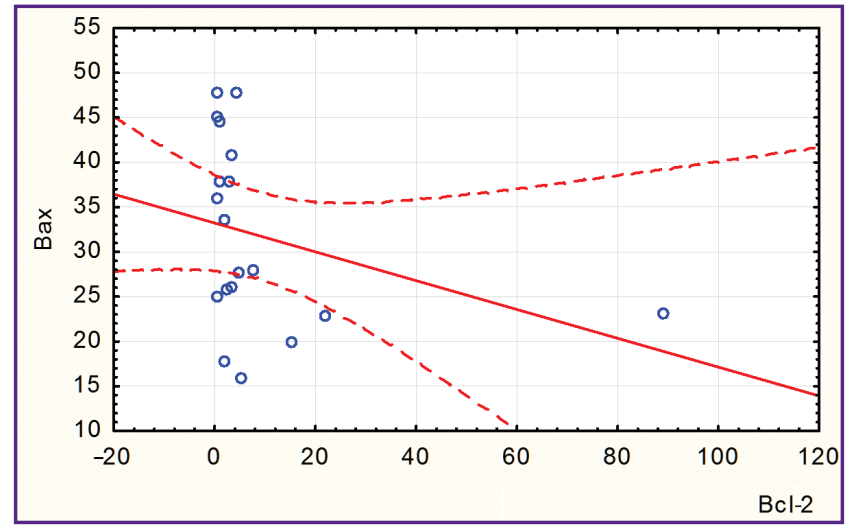

Figure 1. Negative correlation between the Bcl-2 and Bax values in patients with hyperechoic (calcified) atherosclerotic plaque

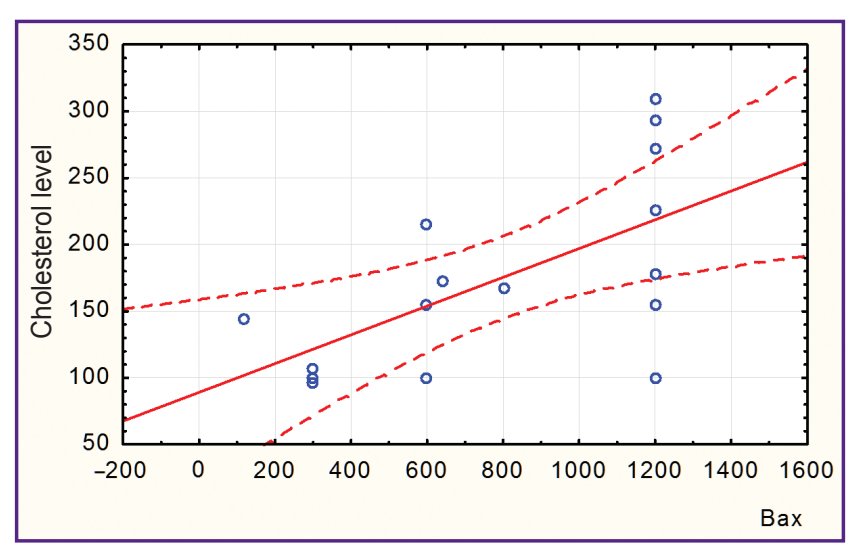

Figure 2. Correlation between Bax values and cholesterol levels in patients with hyperechoic (calcified) atherosclerotic plaque 
fact that cell apoptosis inside an AP is associated with vascular wall remodeling, a release of $\mathrm{IL}-1$ and $\mathrm{IL}-8$, an activation of monocyte chemoattractant proteins, and an increased prothrombogenicity following thrombin activation. The data obtained in this study are consistent with the results of other animal studies [13, 14], which showed that in early atherosclerotic lesions, the number of cells undergoing apoptosis did not exceed $10 \%$ but this number increased as the disease progressed. The proapoptotic markers Fas and caspase- 3 were detected in the endothelium and the SMC media component of the arterial wall close to the lumen of the vessel. The antiapoptotic protein $\mathrm{Bcl}-2$ was found in macrophages and SMCs in the deeper layers of the vascular wall.

The present study shows that the increased level of Bax is associated with the deposition of calcium in the plaques. This is due to the fact that the matrix vesicle-like structures in the plaques are considered to be apoptotic residues that should be instantly cleared by adjacent phagocytes. In the predominantly cell-free lipid core of the AP, phagocytosis of apoptotic cells can be slowed by oLDL that compete with these cells for binding to phagocytes. The remaining non-phagocytosed apoptotic cells can undergo secondary necrosis, which is subsequently calcified.

It should be noted that the apoptotic bodies themselves can accumulate and bind calcium. In the literature, we have found only one report on this subject. Thus, in an in vitro experiment, Proudfoot et al. [15] showed that a caspase inhibitor reduced the calcification of cells in APs.

In this study, the observed correlation between the levels of Bax and serum cholesterol suggests that an increased amount of cholesterol may activate the mitochondrial apoptosis pathway. Cholesterol is part of the cell membrane and, when increased, can change its permeability, contributing to the destabilization and rupture of lysosomes, which, in turn, causes cell death. In addition, the proapoptotic effect of cholesterol may be due to a decrease in antioxidant enzymes (superoxide dismutase and glutathione peroxidase) with an increased generation of reactive oxygen species. According to one study [16], oxidized LDL are able to stimulate receptor-mediated apoptosis followed by activation of caspases and pro-apoptotic protein p53. Our study suggests that the elevated serum cholesterol in patients with lower limb ASO is paralleled with elevated markers of the mitochondrial apoptotic pathway, namely $\mathrm{Bcl}-2$ protein.

To improve the accuracy and reliability of predicting the progression of atherosclerotic lesions in the vascular wall and to facilitate the search for novel therapies, further studies on apoptotic proteins and their relationship with serum cholesterol are warranted.

\section{Conclusion}

The expression of anti-apoptotic protein $\mathrm{Bcl}-2$ is reduced, and that of proapoptotic protein Bax increased in hyperechoic (calcified) atherosclerotic plaques, which indicates the activation of apoptosis in advanced atherosclerotic lesions.

An increased amount of cholesterol in the blood serum of patients with lower limb atherosclerosis obliterans is associated with the activation of the mitochondrial apoptotic pathway in calcified atherosclerotic plaques.

Research funding. There was no financial support for this study.

Conflicts of interest. There are no conflicts of interest related to this study.

\section{References}

1. Marchenko A.V., Vronskiy A.S., Myalyuk P.A., Kamenskikh M.S. Historical aspects and the current state of treatment of combined coronary and carotid artery disease. Kompleksnye problemy serdečno-sosudistyh zabolevanij 2020; 9(1): 74-81.

2. Strelnikova E.A., Trushkina P.Yu., Surov I.Yu., Korotkova N.V., Mzhavanadze N.D., Deev R.V. Endothelium in vivo and in vitro. Part 1: histogenesis, structure, cytophysiology and key markers. Nauka molodykh (Eruditio Juvenium) 2019; 7(3): 450-465, https://doi.org/10.23888/hmj201973450-465.

3. Kalinin R.E., Suchkov I.A., Mzhavanadze N.D., Demikhov V.G., Zhurina O.N., Klimentova E.A. Hemostatic changes in patients with peripheral artery disease before and after bypass surgery. Khirurgiya. Zhurnal imeni N.I. Pirogova 2018; 8: 46-49, https://doi.org/10.17116/hirurgia2018846.

4. Pshennikov A.S., Deev R.V. Morphological illustration of alterations in the arterial endothelium in ischemic and reperfusion injuries. Rossijskij mediko-biologiceskij vestnik imeni akademika I.P. Pavlova 2018; 26(2): 184-194.

5. Paone S., Baxter A.A., Hulett M.D., Poon I.K.H. Endothelial cell apoptosis and the role of endothelial cell-derived extracellular vesicles in the progression of atherosclerosis. Cell Mol Life Sci 2019; 76(6): 1093-1106, https://doi.org/10.1007/s00018-018-2983-9.

6. Gonzalez L., Trigatti B.L. Macrophage apoptosis and necrotic core development in atherosclerosis: a rapidly advancing field with clinical relevance to imaging and therapy. Can J Cardiol 2017; 33(3): 303-312, https://doi.org/10.1016/j. cjca.2016.12.010.

7. Werner N., Wassmann S., Ahlers P., Kosiol S., Nickenig G. Circulatin CD31+/annexin $\mathrm{V}^{+}$apoptotic microparticles correlate with coronary endothelial function in patients with coronary artery disease. Arterioscler Thromb Vasc Biol 2006; 26(1): 112-116, https://doi.org/10.1161/01. atv.0000191634.13057.15.

8. Su G., Sun G., Liu H., Shu L., Liang Z. Downregulation of miR-34a promotes endothelial cell growth and suppresses apoptosis in atherosclerosis by regulating Bcl-2. Heart Vessels 2018; 33(10): 1185-1194, https://doi.org/10.1007/s00380-018$1169-6$.

9. Garratt K.N., Edwards W.D., Kaufmann U.P., Vlietstra R.E., Holmes D.R. Jr. Differential histopathology of primary atherosclerotic and restenotic lesions in coronary arteries and saphenous vein bypass grafts: analysis of tissue obtained from 73 patients by directional atherectomy. J Am Coll Cardiol 1991; 17(2): 442-448, https://doi.org/10.1016/s07351097(10)80113-5. 


\section{BIOTECHNOLOGIES}

10. Kalinin R.E., Suchkov I.A., Klimentova E.A., Egorov A.A., Povarov V.O. Apoptosis in vascular pathology: present and future. Rossijskij mediko-biologiceskij vestnik imeni akademika I.P. Pavlova 2020; 28(1): 79-87.

11. Singh R., Letai A., Sarosiek K. Regulation of apoptosis in health and disease: the balancing act of BCL-2 family proteins. Nat Rev Mol Cell Biol 2019; 20(3): 175-193, https:// doi.org/10.1038/s41580-018-0089-8.

12. Clarke M.C., Figg N., Maguire J.J., Davenport A.P., Goddard M., Littlewood T.D., Bennett M.R. Apoptosis of vascular smooth muscle cells induces features of plaque vulnerability in atherosclerosis. Nat Med 2006; 12(9): 10751080, https://doi.org/10.1038/nm1459.

13. Norata G.D., Tonti L., Roma P., Catapano A.L. Apoptosis and proliferation of endothelial cells in early atherosclerotic lesions: possible role of oxidised LDL. Nutr Metab Cardiovasc Dis 2002; 12(5): 297-305.
14. Akishima Y., Akasaka Y., Ishikawa Y., Lijun Z.,

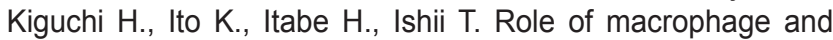
smooth muscle cell apoptosis in association with oxidized low-density lipoprotein in the atherosclerotic development. Mod Pathol 2005; 18(3): 365-373, https://doi.org/10.1038/ modpathol.3800249.

15. Proudfoot D., Skepper J.N., Hegyi L., Bennett M.R., Shanahan C.M., Weissberg P.L. Apoptosis regulates human vascular calcification in vitro: evidence for initiation of vascular calcification by apoptotic bodies. Circ Res 2000; 87(11): 10551062, https://doi.org/10.1161/01.res.87.11.1055.

16. Chen Y., Zhou H., He C., Wang T., Zhang G., Zhang P.,

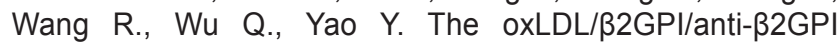
antibody complex induces apoptosis of human umbilical vein endothelial cells by promoting the production of reactive oxygen species. Xi Bao Yu Fen Zi Mian Yi Xue Za Zhi 2019; 35(3): 223-229. 